\title{
Teaching Job Search Written And Oral Communication Skills Through An Integrated Approach
}

Lon Addams, Weber State University, USA

Denise Woodbury, Southern Utah University, USA

\begin{abstract}
Business educators understand the value of improving students' written and oral communication skills. However, too often assignments used to develop these important skills are taught in isolation. The purpose of this article is to enhance a student's written and oral skills by integrating all aspects of the job search written documents and interview practice while utilizing a student-selected job announcement. Each student must find a job announcement for an internship or career position that is consistent with the student's major. The job announcement should list the organization's needs in terms of degree required and specific skills. This article outlines an integrated process of teaching written and oral communication skills through the entire job search. Thus, the job announcement is the focal point for the student's resume, cover letter, career portfolio, and mock interview. Student feedback from the integrated process described in this article has been very positive and rewarding. Students consistently indicate their satisfaction when they successfully apply their self-marketing tools and secure a desired position prior to graduation.
\end{abstract}

Keywords: teaching job search skills, job announcement, resume, cover letter, career portfolio, mock interview

\section{INTRODUCTION}

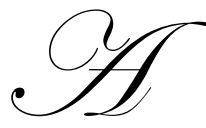

s business communication instructors, we understand the value of improving students' writing and oral communication abilities. Yet, too often the assignments used to develop these important skills are taught in isolation. The purpose of this article is to enhance a student's writing and oral performance by integrating all aspects of the job search while focusing on one real open position selected by the student. Students appreciate practical, applied assignments. The process described below captures the "real-world" criterion students so often allude, yet appreciate.

In the business curricula, students are taught to communicate and market goods and services. However, some researchers believe business educators are less diligent in teaching them to market themselves. For example, Campbell (2002 and 2006) and McPherson (1998) suggest that students need to be more engaged in marketing their own skills, knowledge, and abilities. McCorkle, Alexander, Reardon \& Kling's (2003) job search research led them to the position that marketing educators have the responsibility to teach students self-marketing/job search skill development; otherwise, good students can get bad jobs, which reflects not only on the students but also on colleges and universities providing business education. Business communication instructors need to lead the way among their colleagues in this important role of helping students market themselves.

Most business communication instructors give college students assistance in writing a resume and application/cover letter but may not tailor the resume and letter to a specific career announcement upon graduation. Yet, a specific position announcement may require very specific skills and knowledge (such as Asst. Investment Officer-Wells Fargo Bank). Tailoring the resume to a real opportunity in an advertisement found in a journal, newspaper, or internet posting may not be part of the learning experience in some business communication courses. 
Further, some business communication instructors spend a class period giving interviewing tips but do not provide practice time for the students to hone their oral skill. Some business communication instructors teach their students the usefulness of having a career portfolio but may not require each student to prepare a career portfolio to be used in a job interview.

In this article, we have outlined an integrated process of teaching written and oral communication skills through the entire job search. Assignments are suggested that focus on a specific job in the student's major and utilize written or oral skills for each of the segments, as graphically shown below:

\section{JOB ANNOUNCEMENT - RESUME - COVER LETTER - CAREER PORTFOLIO - MOCK INTERVIEW}

Each of these areas will be discussed along with teaching suggestions and student assignments. Written and oral communication skills will be highlighted.

\section{JOB ANNOUNCEMENT}

Various methods can be used to give the students some direction in finding a real job position in a real company that would be appropriate for the particular major. The students should be encouraged to find a position that they would desire upon graduation. One substitution could be made that is also very practical: finding an internship announcement-in the student's major. Many students actually carry the assignment all the way to accepting the position.

One method used to help the student find a real position available is to invite the career counselor at your institution to speak for part of a class period on the benefits of utilizing the career center services and on the job announcements currently available for internships and career positions upon graduation. Typically, the career counselor has access to a number of opportunities. Further, the career counselor could give tips on the value of networking and could provide other resources in finding job opportunities, including the value of student organization membership. The side benefit of bringing in the career counselor is providing the students with the chance of connecting with the career counselor for immediate and/or future assistance.

Another method used to assist in locating potential company career positions is to invite two-three human resource managers from local firms to take a few minutes of class time to promote the need for excellent communication skills in resumes, cover letters, career portfolios, and job interviews. This speaker could also share job announcements for current internships available and for career positions in accounting, finance, marketing, management, economics, information technology, etc. Most human resource managers have written job announcements to share. Accordingly, a proposed assignment follows:

Assignment: Require the student to submit a typed copy of an actual announcement (internship or career position) which she/he will utilize for the integrated approach discussed in the following assignments. [Assign appropriate number of points.]

The key to the entire integrated approach is to ensure that each student picks a viable position. Some students mistakenly choose a position (like Vice President of Marketing in a large firm) that will take several years to acquire the needed experience for this more senior position. If the student has picked a job announcement for a position that is outside his/her major, the student needs to re-submit the assignment with a job announcement within his/her major course of study. At times, an internship announcement will not specifically identify the type of business major needed ("internship at Boeing"). If this occurs, have the student contact the organization and document the type of major needed. The student should tailor the resume, cover letter, career portfolio, and interview content to the skills and knowledge required for the major. Consequently, the value of ascertaining a viable situation cannot be overstated.

\section{RESUME PREPARATION}

When writing a resume, the student should tailor the resume to the position found in the job announcement 
(assignment above). With the position evident to the student, he/she should jot down the critical skills and knowledge needed for this particular internship or career position. At times, the job announcement may list the critical skills, related experience, and knowledge the company desires for this particular job.

As the instructor, place the job announcement next to the submitted student resume; examine the job objective stated by the student: "Seeking Asst. Investment Officer at Wells Fargo Bank." Does the stated objective match the job announcement the student selected? Now, determine whether the student has "sold" himself/herself as you scrutinize the bullet points in the education, work experience, and other leadership/service sections of the resume.

Two ingredients are needed to mold a resume that sells: (1) emphasis on accomplishments, skills developed, and contributions to the organization and (2) positive appeal.

\section{Emphasis on Accomplishments}

Under a student's job experience section, he/she needs to describe unique, specific contributions to a past or present organization. For example, perhaps the student increased sales by 10 percent over pre-set company goals for the last three months. Or, perhaps the student sharpened human resource management skills by developing a new performance appraisal instrument, resulting in both management and communicating more effectively with the new performance review process. Accordingly, the student should stress accomplishments and contributions in past jobs rather than a long list of dull job responsibilities.

Students must state accomplishments and attributes gained in specific jobs which focus on the skills needed in the job announcement (discussed in the earlier assignment). Thus, in the work experience section, the student should bullet two-three contributions or skills developed at a particular company. Credibility is built on facts, not simply trite, general expressions such as "I am a great communicator." This bullet sells: "increased personal sales by 20 percent over a three-month period." Also, by indicating a skill developed on a particular job, the student shows he or she is teachable. Further, students must understand that they need to specifically indicate how they have added value to companies and that they have the skills required for this open position.

\section{Positive Appeal}

The second ingredient in crafting a resume that sells is positive appeal. By accentuating the positive, the student increases value when the interviewer or potential manager glances briefly over the resume. The most important items should be strategically positioned first in any bullet list and in the resume overall.

Another way to show positive appeal is to address the needed skill set for the open position by crafting an effective "Key Qualifications" section immediately following "Job Objective." Two or three one-line bullet phrases should capture (1) the status of the student's education ("First semester senior in finance degree program") and (2) a summary of work experience, preferably related work experience ("Six-month finance internship at Key Bank"). In this way, the recruiter will probably say, "Yes, this person has the education, experience, and skills I need!"

The student should "sell" the resume by stressing the skills and knowledge gained through specific experiences noted on the resume. Power verbs should be used in bullet lists, such as "implemented, streamlined, developed, created, etc. The focus should be on selling the skills and work characteristics outlined in the job announcement. This is done by (1) emphasizing accomplishments, contributions, and skills and (2) using positive appeal through power verbs and implementing a "selling" strategy throughout the resume.

Assignment: Require the student to submit a typed resume for an internship or career position which she/he will utilize for this integrated approach; a copy of the position description should be attached. [Assign appropriate number of points.] 


\section{COVER LETTER PREPARATION}

The cover letter should be used to personally connect with the reader. The recruiter, human resource manager, or hiring manager who reads the student's cover letter should be able to grasp quickly that this job seeker meets the chief qualifications for the job. Hence, the cover letter must sell his or her strong points that align with the company's needs.

The first paragraph should immediately reaffirm the position desired. The middle paragraphs should sell qualifications by written text and by a bullet list of two or three of the key qualifications possessed that meet company requirements. Finally, the closing paragraph should reaffirm enthusiasm for the possible position and request an interview.

Assignment: Require the student to submit a typed cover letter-along with the resume--for an internship or career position which she/he will utilize for this integrated approach; a copy of the position description should be attached. [Assign appropriate number of points.]

\section{CAREER PORTFOLIO PREPARATION}

Recently, the Occupational Outlook Quarterly (2006) describes how employers are better able to determine the competency of a job seeker when provided with a collection of materials such as a resume, transcripts, letters of recommendation, and work samples. Powell and Jankovich (1998) pointed out that any documented work performance samples enhances the student's ability to pass the initial interview screening process.

Moody, Stewart, and Bolt-Lee (2002) determined that a career portfolio demonstrates students' written communication skills, technological ability, and creativity. In their survey to representative employers (provided by the National Association of Colleges and Employers), these researchers noted that 71 percent of respondents agreed that portfolios were moderately-to-extremely helpful in showcasing students' abilities, but they stressed that portfolios must be presented in an efficient and concise manner. Recruiters were interested in seeing portfolios that provided concrete examples of student achievements.

One of the major reasons for assembling a career portfolio is to present eye-catching, documents that enhance the "selling" process of the job candidate. Whenever an interviewee can catch the interviewer's interest, the interviewee's chances for a career job or internship offer increase dramatically. The professionalism shown may be perceived to carry over to work assignments. Signs of preparation and commitment can be communicated to the interviewer.

Artifacts build credibility. Interviewers often hear a candidate say "I am a good communicator" or "I am a good writer." Contrast that statement with a student who can open up his/her portfolio and show the interviewer a tri-fold marketing brochure or a copy of a website produced for U.S. Bank. Presenting materials that enhance your credibility makes good business sense. A well-designed and documented career portfolio may be the edge needed to secure a prized internship or career position.

Naturally, each student's career portfolio will be different. A student needs to tailor his or her portfolio to emphasize the skills and abilities acquired that meets the qualifications for a particular internship or career position. Below, general items for all business majors are shown, followed by an example for a finance major (in italics) of suggested documents produced:

- $\quad$ Title Page ("Career Portfolio" and "Your Name")

- $\quad$ Contents Page (items/documents listed in order of appearance)

- $\quad$ Cover Letter (tailored to the specific job opening)

- $\quad$ Resume (tailored to the specific job opening)

- $\quad$ Academic Plan of Study (relevant courses titles - not course numbers)

- $\quad$ Professional Goals (short term and long term) 
- Written and Visual Documents (e.g., case response, research report, PowerPoint presentation slides, brochure, client proposal, new product description, etc.)

- $\quad$ Evidence of Skills \& Knowledge Acquired from Academic Preparation and Work Experience **[See specific documents for a finance major below - in italics]

- $\quad$ Leadership Experiences

- $\quad$ Community Involvement

- $\quad$ Performance Appraisals

- $\quad$ Awards/Certificates/Honors

- $\quad$ Letters of Commendation

- $\quad$ List of References

- $\quad$ Solicited Letters of Recommendation

**Type of Business Major with Accompanying Documents Personally Produced

Finance: (1) survivor portfolio, (2) risk analysis, (3) capital budgeting case, (4) ratio analysis, (5) investment portfolio, (6) leasehold evaluation.

A student should use a professional looking binder with plastic sheet protectors in order to present the best image. Once this "selling package" or career portfolio is assembled, the student needs to get the portfolio into the hands of the interviewer during the interview.

Assignment: Require the student to submit career portfolio for an internship or career position which she/he will utilize for this integrated approach; a copy of the position description should be attached. [Assign appropriate number of points.]

\section{MOCK INTERVIEW PREPARATION}

Being able to highlight appropriate skills in the context of a job's requirements in a stressful situation is essential to a job seeker's success. Relevant literature supports the need to teach students how to interview (Maurer, Solamon, Andrews, \& Troxtel 2001; Moynihan, Roehling, LePine, \& Boswell, 2003). Further, Marks and O'Connor (2006) stress the need for practice time using techniques taught in class; they designed a round-robin mock interview and found that students gained meaningful insights into their strengths and weaknesses from their performance.

When teaching the class interviewing techniques, the business communication instructor has two challenges: (1) presenting valuable interview techniques and (2) providing practice time to hone interview skills. Again, the emphasis should be on selling skills, attributes, knowledge, and work characteristics that meet the qualifications for the intended job position.

In preparing students for the mock interview assignment, the business communication instructor should consider typical questions the interviewer is likely to ask. The focus should always be on selling those skills acquired by the student that are needed in the position desired. For example, if the interviewer asked for a key strength, the student (interviewee) should focus on a specific skill needed for the particular job. If the open position required solid writing skills, the student could show the interviewer a case analysis report, a business plan, or a brochure he or she devised at work or in a class.

Now, the instructor needs to give each student an opportunity to practice. Various methods are used by some communication instructors. To obtain the best results, have a mock interview done outside of class. Some instructors have facilities to video-record interviews somewhere on campus where video-recording can be done. However, we have found positive results by simply having pairs of students meet outside of class when they can arrange both of their schedules.

Assigning students randomly with the class list works well. We avoid letting students choose who they 
will interview. We establish a job interview situation where there is some pressure. When students do not know each other well, there is some pressure to present the best self. Student pairs are required to meet outside of class and act as interviewer for 15-20 minutes then as an interviewee for 15-20 minutes. Students come professionally dressed and take their career portfolios to utilize with the interviewer.

Finally, a written critique is needed. Each student should ask the interviewer (fellow student assigned) for a realistic critique on answers given, on nonverbal communication exhibited, and on the use of the career portfolio in the interview. Then, the student should prepare a self-critique on his/her strengths and weaknesses as an interviewee, using the interviewer's comments to help identify specifics. This critique could be in memo form (one page) or an extended two-page report to the instructor.

Assignment: (1) Require the student to conduct a mock interview for an internship or career position (resume and cover letter included in portfolio) as part of this integrated approach. (2) Require the student to submit a typed memo or report based on strengths and weaknesses as an interviewee. [Assign appropriate number of points.]

\section{CLOSING REMARKS}

Student responses and feedback from the integrated process have been very positive and rewarding. Students consistently indicate their satisfaction with their new tools as they have followed a specific job announcement through preparation of a resume, cover letter, career portfolio, and a mock interview. Self-esteem is heightened. Some students realistically become aware of needed skills in certain areas and are determined to take action to close gaps in qualifications for a specific type of job in their major course of study. Some studentsduring the semester-actually secure the internship or potential career position desired.

\section{AUTHOR INFORMATION}

Lon Addams is professor of management and a Dee Smith Fellow in the Goddard School of Business \& Economics at Weber State University, Ogden, UT. He publishes in methodology and research topics in such areas as corporate communication, job search techniques, and teaching methodology. He consults with businesses on associated topics.

\section{REFERENCES}

1. Campbell, N. (2002). Getting rid of the yawn factor: Using a portfolio assignment to motivate students in a professional writing class. Business Communication Quarterly, 65(3), 42-54.

2. Marks, Melanie, \& O'Connor, Abigail H. (2006). The Round-Robin Mock Interview, Business Communication Quarterly, 69(3), 264-275.

3. Mauer, T.J., Solamon, J.M., Andrews, K.D., \& Troxtel, D.D. (2001). Interviewee coaching, preparation, strategies, and response strategies in relation to performance in situational employment interviews: An extension of Maurer, Solamon, and Troxtel (1998). Journal of Applied Psychology, 86, 709-717.

4. Moynihan, L.M., Roehling, M.V., LePine, M.A., \& Boswell, W.R. (2003). A longitudinal study of the relationships among job search, self-efficacy, job interviews, and employment outcomes, Journal of Business and Psychology, 18, 207-233.

5. McCorkle, D., Alexander, J., Reardon, J. \& Kling, N. "Developing self-marketing skills: Are marketing students prepared for the job search?", Journal of Marketing Education, 25(3), 196-207.

6. McPherson, W. (1998). Student perception about business communication in their careers. Business Communication Quarterly, 61(2), 68-79.

7. Moody, J., Stewart, B. \& Bolt-Lee, C. Showcasing the Skilled Business Graduate: Expanding the Tool Kit. Business Communication Quarterly, 65(4), 21-36.

8. Occupational Outlook Quarterly (2006). Career portfolios: Jobseekers show their competencies. 50(2), 26.

9. Powell, K. S., \& Jankovich, J. L. (1998). Student portfolio: A tool to enhance the traditional job search. Business Communication Quarterly, 61(4), 72-82. 